\title{
Outbreak of viral haemorrhagic septicaemia (VHS) in seawater-farmed rainbow trout in Norway caused by VHS virus Genotype III
}

\author{
O. B. Dale ${ }^{1}$, I. Ørpetveit ${ }^{1}$, T. M. Lyngstad ${ }^{1}$, S. Kahns ${ }^{2}$, H. F. Skall ${ }^{2}$, N. J. Olesen ${ }^{2}$, \\ B. H. Dannevig ${ }^{1, *}$
}

${ }^{1}$ National Veterinary Institute, PO Box 750 Sentrum, 0106 Oslo, Norway

${ }^{2}$ European Community Reference Laboratory for Fish Diseases, National Veterinary Institute, Technical University of Denmark, Hangøvej 2, 8200 Århus N, Denmark

\begin{abstract}
We describe the finding of a novel viral haemorrhagic septicaemia virus (VHSV) Genotype III strain that caused disease of both a neurological and septicaemic nature in seawater-farmed rainbow trout Oncorhynchus mykiss in Storfjorden, Norway. In November 2007, an outbreak of VHS associated with slightly elevated mortality was confirmed at a seawater site rearing rainbow trout (90 to $440 \mathrm{~g}$ ). Within 3 to $4 \mathrm{mo}$, the disease was recognised in 3 neighbouring sea sites with ongrowing rainbow trout. The clinical, gross pathological and histopathological findings were in accordance with VHS, and the diagnosis was confirmed by the detection of VHSV in brain and internal tissues by immunohistochemistry, cell culture and reverse transcriptase PCR (RT-PCR). Sequence analysis of the G-gene revealed that the isolated virus clustered with VHSV Genotype III and that the Norwegian isolate represents a unique strain of VHSV. The pathogenicity of the virus strain to rainbow trout and Atlantic salmon Salmo salar was examined using infection experiments. In immersion trials, the Norwegian isolate produced a cumulative mortality of $70 \%$ in rainbow trout, while nearly $100 \%$ mortality was obtained after intraperitoneal injection of the virus. For Atlantic salmon, no mortality was observed in immersion trials, whereas $52 \%$ mortality was observed after intraperitoneal injection. The Norwegian isolate thus represents the first VHSV of Genotype III pathogenic to rainbow trout.
\end{abstract}

KEY WORDS: VHS · VHSV · Genotype III · Novirhabdovirus $\cdot$ Rainbow trout $\cdot$ Sea farm

\section{INTRODUCTION}

Viral haemorrhagic septicaemia (VHS) is a severe disease historically affecting farmed rainbow trout Oncorhynchus mykiss in Europe (Wolf 1988) and is still considered to be one of the most serious viral diseases in aquaculture. The disease manifestations of VHS include both a haemorrhagic septicaemia, and an anaemic and nervous form (Schäperclaus 1979). The infection may persist subclinically in rainbow trout once fish are infected, and covert carriers of cultured or wild fish have been suggested to be reservoirs of VHSV (Jørgensen 1982, Enzmann \& Konrad 1985).
The causative agent, VHS virus (VHSV), belongs to the genus Novirhabdovirus of the family Rhabdoviridae (Walker et al. 2000). During the last 2 decades, VHSV has been isolated in wild fish from both freshand marine waters (reviewed by Skall et al. 2005) throughout the temperate part of the northern hemisphere, and VHS has been recorded in farmed marine species such as turbot Scophthalmus maximus (Schlotfeldt et al. 1991, Ross et al. 1995). In North America and Asia, VHS primarily causes mortality in wild fish (Meyers et al. 1999, Nishizawa et al. 2002) and a major epidemic is ongoing with mass mortality in several wild species in the North American Great Lakes (Groocock et al. 2007, Lumsden et al. 2007). There are also reports 
of clinical outbreaks in farmed Japanese flounder Paralichthys olivaceus (Isshiki et al. 2001) and reports of isolation of VHSV in Atlantic salmon Salmo salar (Traxler et al. 1995, G. Traxler pers. comm., reported in Skall et al. 2005).

VHSV is enveloped with a single, negative-stranded RNA segment encoding 5 structural proteins and one non-structural protein. Phylogenetic studies of the nucleoprotein (N) and glycoprotein (G) encoding genes of VHSV have identified 4 main genotypes (I to IV) that seem to be more associated with geographical origin than with fish species (Snow et al. 1999, 2004, EinerJensen et al. 2004, 2005). All freshwater isolates belong to Genotype I or IV whereas seawater isolates are represented in all 4 genotypes. Most VHSV isolated from rainbow trout in European freshwater farms cluster in a subgroup of Genotype I (Ia), while isolates from several marine species, in the Baltic Sea, Kattegat and Skagerrak belong to another subgroup, Ib. Virus isolated from outbreaks of VHS in sea-farmed rainbow trout off the Swedish coast within the seawaters of Kattegat (Nordblom \& Norell 2000) were also of Genotype Ib, whereas the isolates from VHS outbreaks in Finnish sea-reared rainbow trout grouped together in Genotype Id (RajaHalli et al. 2006). This genotype also harbours an old Norwegian isolate (NO-A163.68). The VHSV Genotype II has been isolated from herring Clupea harengus, sprat Sprattus sprattus and cod Gadus morhua in the Baltic Sea, whereas Genotype III has been isolated from marine species such as Norway pout Trisopterus esmarkii, haddock Melanogrammus aeglefinus, whiting Merlangius merlangus, cod and herring in the North Sea and Skagerrak (Skall et al. 2005). VHSV Genotype IV seems to be restricted to North America and Asia and has been isolated from both seawater and freshwater species (Lumsden et al. 2007).

The pathogenicity of the various marine isolates has been evaluated by infection trials, as no suitable genetic virulence marker has been identified for VHSV. Generally, in infection experiments with rainbow trout VHSV isolated from various marine species may cause no or low mortalities by immersion, while significant mortality can be obtained following intraperitoneal injection of the same virus isolates (Skall et al. 2004). The Danish, Finnish and Swedish VHSV isolates from sea-farmed rainbow trout of Genotype Ia, Id and Ib, respectively, are pathogenic to rainbow trout fingerlings challenged with both immersion and intraperitoneal injection $(20-70 \%$ and $90-100 \%$ mortality, respectively). Sequence analysis of the entire coding regions of the genome indicates that only a small number of amino acid residues may be involved in the determination of VHSV virulence in rainbow trout (Betts \& Stone 2000). RNA viruses tend to display very high mutation rates and thereby a high capability of adaptation. Therefore, the presence of VHSV in the marine environment is considered to represent a threat to sea-farmed susceptible species.

In November 2007, slightly increased mortality and abnormal swimming patterns were observed in seafarmed rainbow trout in western Norway. Based on gross pathological and histopathological examinations, VHS was suspected and the diagnosis verified by immunohistochemical and virological examinations. In the present study, the case history and the genetic characterisation of the causative virus are presented in addition to experimental infection trials with rainbow trout and Atlantic salmon challenged with isolated virus.

\section{MATERIALS AND METHODS}

Sampling. For the initial diagnosis, rainbow trout tissue samples were collected on 2 occasions and submitted to the National Veterinary Institute (NVI), Oslo. The first sampling was performed by the local fish health service, in connection with an inspection on 15 November 2007 (7 fish). A follow-up sampling was initiated by the Norwegian Food Safety Authority (NFSA) on 26 November 2007 (10 fish). At this latter sampling, duplicate samples were submitted to the NVI and to the European Community Reference Laboratory (CRL) for Fish Diseases, Århus, Denmark. Live rainbow trout with behavioural changes were collected from 7 of a total of 20 net pens. Samples of gill, heart, liver, pyloric caeca, spleen, kidney and muscle with skin attached were collected and transferred to formalin $(10 \%$ phosphate-buffered formalin) and pooled tissue samples consisting of kidney, spleen and heart were transferred to transport medium (Eagle's Minimum Essential Medium [EMEM], pH 7.6, supplemented with $10 \%$ newborn bovine serum and $100 \mathrm{\mu g} \mathrm{ml}^{-1}$ gentamicin). Brain was only included in the second sampling. Kidney samples were also submitted in RNAlater ${ }^{\circledR}$ in the first sampling. Subsequent samplings of fish from other sites were performed in the same manner, but included dead fish. All examinations were performed on samples from individual fish.

Histopathology and immunohistochemistry. Formalin-fixed tissue samples were processed and embedded in paraffin wax according to standard procedures. Sections (4 to $6 \mu \mathrm{m}$ ) were stained with haematoxylin and eosin (H\&E) and examined by light microscopy.

Immunohistochemical (IHC) examination was performed essentially according to Brudeseth et al. 2002 with minor modifications (Taksdal et al. 2007). The monoclonal antibody (MAb) IP5B11 against the VHSV nucleoprotein (Lorenzen et al. 1988) was used as the primary antibody and biotinylated rabbit anti-mouse 
immunoglobulin (Dako) as the secondary antibody before incubation with streptavidin-alkaline-phosphatase complex (Amersham Biosciences). The primary antigen/antibody reaction was visualised by adding Fast Red salt (Sigma-Aldrich) in Fast Red substrate solution.

Virus isolation and identification. Pooled pieces of tissue from each of the sampled fish were homogenized and the samples cleared by low-speed centrifugation according to routine procedures. The supernatants were inoculated in 10-fold dilutions onto subconfluent monolayer cell cultures of bluegill Lepomis macrochirus fry fibroblast (BF-2) (Wolf et al. 1966) and Epithelioma papulosum cyprini (EPC) (Fijan et al. 1983) in 24 well tissue culture plates as described in Commision Decision 2001/183/EC (Anonymous 2001) and in Lorenzen et al. (1999). Inoculated cultures were incubated at $15^{\circ} \mathrm{C}$ and inspected regularly with a microscope for the occurrence of cytopathic effect (CPE) at $40 \times$ magnification. When total CPE was evident, the cell culture medium was collected for virus identification by an indirect immunofluorescence test (IFT) or ELISA.

Briefly, for IFT, BF-2 and EPC cells grown in 96 well tissue culture plates were inoculated with cell culture supernatants in several dilutions and incubated at $15^{\circ} \mathrm{C}$ for 24 to $48 \mathrm{~h}$. After fixation in $80 \%$ acetone, the monolayers were incubated with MAb IP5B11 following incubation with biotin-labelled goat anti-mouse Ig (DAKO) and then a final incubation with fluorescein isothiocyanate (FITC)-labelled strepatvidin (DAKO). Appropriate virus positive and negative controls were included. The cell cultures were examined in an inverted epifluorescence microscope.

The virus was identified as VHSV by ELISA as described by Skall et al. 2004 .

Reverse trancriptase-PCR (RT-PCR) and sequence analysis. Nucleic acid was extracted from rainbow trout tissue samples with the NucliSens ${ }^{\circledR}$ EasyMAG $^{\mathrm{TM}}$ platform for total nucleic acid extraction (BioMérieux) according to the manufacturer's instructions. The initial diagnostic RT-PCR was performed using the QIAGEN OneStep RT-PCR Kit (Qiagen) according to the manufacturer's instructions. The primers, V2F ( $5^{\prime}$-TGG GAC GAA ACT TTG AGA GG-3') and V2R (5'-GAT CAC AGG GTG GTC AAG G-3'), were designed to amplify a $323 \mathrm{bp}$ fragment of the G-gene using the Oligo Primer Analysis Software, v. 6.68 (Molecular Biology Insights). These primers have been validated through the participation of the annual interlaboratory profiency tests organized by European Community Reference Laboratory (CRL) for Fish Diseases, Århus, Denmark. The cycling conditions were: $50^{\circ} \mathrm{C}$ for $30 \mathrm{~min}, 95^{\circ} \mathrm{C}$ for $15 \mathrm{~min}$, followed by 40 cycles of $94^{\circ} \mathrm{C}$ for $1 \mathrm{~min}, 55^{\circ} \mathrm{C}$ for $1 \mathrm{~min}$ and $72^{\circ} \mathrm{C}$ for $1 \mathrm{~min}$, and finally $72^{\circ} \mathrm{C}$ for $10 \mathrm{~min}$. The PCR products were purified with
ExoSAP-IT ${ }^{\circledR}$ (USB) according to the manufacturer's protocol and sequenced using the BigDye ${ }^{\circledR}$ Terminator v. 3.1 Cycle Sequencing Kit (Applied Biosystems). Full length G-gene sequences were amplified, using the GD +/- primer pair primers and sequenced as previously described (Einer-Jensen et al. 2004). The cycling conditions were: $50^{\circ} \mathrm{C}$ for $30 \mathrm{~min}, 95^{\circ} \mathrm{C}$ for $15 \mathrm{~min}$, followed by 35 cycles of $94^{\circ} \mathrm{C}$ for $30 \mathrm{~s}, 55^{\circ} \mathrm{C}$ for $30 \mathrm{~s}$ and $68^{\circ} \mathrm{C}$ for $1 \mathrm{~min}$, and finally $68^{\circ} \mathrm{C}$ for $7 \mathrm{~min}$. Nucleotide sequences reported in this paper have been submitted to the GenBank database and designated accession numbers EU547740 and AM920657 correspond to full length and partial sequences of the G-gene of the NO-2007-50-385 and NO/650/07 VHSV isolates, respectively.

Phylogenetic analysis. Multiple sequence alignment using full length G-gene sequences (1524 nucleotides) was performed using the alignment platform of the CLC Workbench package (v. 4.0, CLC bio). Publicly available sequences from isolates representing all described VHSV genotypes were included in the analysis (EinerJensen et al. 2004, Elsayed et al. 2006). Duplicate sequences were identified manually and excluded from the data set. A phylogenetic tree was generated by the Neighbor-Joining distance algorithm (CLC Workbench package, v. 4.0, CLC bio) using the Jukes-Cantor substitution model (Jukes \& Cantor 1969). The robustness of the tree topology was assessed by using 1000 bootstrap iterations. Bootstrap values exceeding $70 \%$ were considered to indicate significant relatedness.

Infection trials. Infection trials in rainbow trout and Atlantic salmon were performed to test the pathogenicity of the Norwegian VHSV strains in these species. The fish were infected by immersion (bath) or by intraperitoneal (i.p.) injection.

Fish: Rainbow trout fingerlings were $10.1 \mathrm{~g}$ ( $\mathrm{SD}=$ $3.9 \mathrm{~g}$ ) in size and were purchased as eyed eggs approximately 10 mo before infection from a Danish commercial fish farm, officially registered free of infectious pancreatic necrosis virus (IPN), infectious haematopoietic necrosis (IHN) and VHS. The fish were hatched and grown in the wet laboratory facilities of CRL, Århus. Atlantic salmon fingerlings were $5.2 \mathrm{~g}$ (SD = $1.8 \mathrm{~g}$ ) and were purchased $3 \mathrm{~d}$ before infection from a farm breeding progeny of wild caught Atlantic salmon for restocking purpose. The salmon fingerlings, hatched 9.5 mo before infection, originated from parental fish caught in the River Storå in the northwest part of Jutland. The parental fish tested negative for VHS, IHN, IPN and bacterial kidney disease (BKD).

Tanks: The tanks contained 81 of soft freshwater $(2.5$ to $4.5^{\circ} \mathrm{H}$ ) and the aerated water temperature was maintained at $9.6^{\circ} \mathrm{C}\left(\mathrm{SD}=0.6^{\circ} \mathrm{C}\right)$. The water used was groundwater of drinking quality (not chlorinated), and new water was added continuously with no recircula- 
tion. The tanks were kept closed with a transparent lid to prevent contamination by aerosols and prevent fish from jumping out.

Virus isolates: The virus isolate NO-2007-50-385 was passaged once in BF-2 cells and titrated on the same cell type according to standard procedures (Lorenzen et al. 1988).

Positive and negative controls: The highly pathogenic VHSV strain DK-3592B (Lorenzen et al. 1993) isolated from a rainbow trout farm was used as a positive control by immersion only. As a negative control, EMEM with tris-buffer and 10\% newborn calf serum (dilution medium) was likewise used by immersion only.

Trials: Each group of rainbow trout, both positive and negative control fish and test fish, were tested in triplicate with 31 fish in each tank. The Atlantic salmon immersed in virus were tested in duplicate with 75 fish in each tank. Atlantic salmon injected with virus and the negative control fish were only tested in single tanks, with 35 fish in each. Dead fish were removed daily from each tank. The number of dead fish and clinical symptoms of VHS in fingerlings were recorded daily. At the end of the trial, surviving fish were euthanized with an overdose of benzocaine and counted. The sum of surviving fish and fish that died during the trial equalled the number of fish in each tank. The trials were terminated after $28 \mathrm{~d}$.

Immersion trial: To obtain a concentration of approximately $10^{5} \mathrm{TCID}_{50} \mathrm{ml}^{-1}$ water, virus isolates were added to a vial containing $10 \mathrm{ml}$ dilution medium according to their respective titres. Water supply was stopped while virus dilutions were added to each tank, resulting in an immersion exposure time of $2 \mathrm{~h}$, after which the continuous water flow was resumed.

Intra-peritoneal injection trials: Virus isolates were mixed in vials with $10 \mathrm{ml}$ dilution medium to obtain a dose of approximately $10^{5} \mathrm{TCID}_{50}$ per fish in an injection volume of $50 \mu \mathrm{l}$. Fish were anaesthetised by bathing them in benzocaine solution, injected intraperitoneally with a new needle and syringe for each tank group and transferred to tanks supplied with running fresh water.

Virus isolation: Fish that died during the trials and survivors at the end of the trials were sampled for virus isolation. Negative and positive control groups were also sampled. Fish were frozen at $-25^{\circ} \mathrm{C}$ for later examination. In each tank the first 3 fish that died after infection and approximately 10 fish that survived to the end of the trial were individually examined on cell cultures as described in 'Virus isolation and identification'.

Collection of epidemiological data. The epidemiological data from the outbreak site were gathered by the local district offices of the NFSA by means of a predesigned form together with inspection reports from the NFSA. The form focused on variables of fish health, fish stock and management.

\section{RESULTS}

\section{The outbreak}

The outbreak of VHS was confirmed by NFSA on 27 November 2007 at a seawater site rearing rainbow trout located in Storfjorden in the county of Møre and Romsdal, on the west coast of Norway (see Fig. 4). VHS was later confirmed at 3 additional neighbouring sites with on-growing rainbow trout located within a distance of 5 to $7 \mathrm{~km}$ from the primary outbreak site (diagnoses confirmed by NFSA on 29 January 2008, 1 February 2008 and 8 February 2008, respectively). All sites were operated by the same company.

By November 2007 there were approximately 1.8 million fish at the primary outbreak site weighing from 90 to $440 \mathrm{~g}$. The fish were kept in 20 net pens. Monthly mortality at sea site level was reported as $1.7 \%$ in November and 1.8\% in December 2007 (Aquaculture register 2007, Directorate of Fisheries).

Before the outbreak was verified, fish were repeatedly graded on the primary site and moved to 3 neighbouring sites where VHS was later confirmed. The rainbow trout were fed commercial dry pelleted feed. Dead fish (rainbow trout together with cod and saithe Pollachius virens from other sites in the same fjord) were stored in land-based containers close to the primary site.

An eradication zone was established and fish from the primary outbreak site and the 3 neighbouring sites were removed and disposed of by the end of April 2008.

\section{Clinical signs and gross pathology}

In November 2007 the farmer alerted the local fish health service as behavioural changes and slightly elevated mortality had been observed in the fish. On inspection ataxic fish swimming in circles or spirals in the surface water, occasionally with the appearance of cramps, were seen in all 20 net pens. Notably the number of ataxic fish could vary from hour to hour. By necropsy of 7 ataxic fish with no external lesions, 2 fish were found to have pale gills, severe anaemia (haematocrit $<10$ ), pale and grey-orange livers and swollen dark spleens, and 1 of these 2 fish had extensive haemorrhages in the peritoneum covering the pyloric caeca. Among the other 5 fish, 1 had a very dark red liver; otherwise there were no findings except for evidence of lack of feed in the gastrointestinal tract in all 7 fish. On the follow-up sampling of 10 ataxic fish with no visible external lesions, the internal findings were limited to swollen spleens and no feed in the gastrointestinal tract. These observations had not been observed in 
previous disease investigations at the farm. The later samplings at the 3 affected neighbouring sites included both live ataxic fish and dead fish. Similar pathology was found, though some dead fish had more extensive haemorrhages. Furthermore, VHS could be verified up to time of slaughter in April 2008.

\section{Histopathology and immunohistochemistry}

The main histopathological findings corresponding to the haemorrhagic lesions on necropsy were hepatitis with multifocal, sometimes haemorrhagic, necrosis in the liver, endocarditis and haematopoietic necrosis in kidney and spleen. IHC showed staining of VHSV to a variable degree, from sparse staining of endothelial cells and macrophages in the spleen and kidney in rainbow trout sampled live to extensive staining of necrotic haematopoietic tissues, especially in kidney and spleen in fish sampled dead (Fig. 1). In the fish with only nervous signs, changes in the visceral organs were limited to accumulation of blood pigment (haemosiderosis) in the spleen and occasionally hepatitis. The main finding in these fish was meningoencephalitis and the cellular infiltrate of the meninges was mononuclear. In the brain of fish sampled live, small haemorrhages in conjunction with necrotic foci were found. In dead fish with the same necropsy findings, more severe encephalitis with spongy change, neuronal degeneration and gliosis was found. By IHC, strong staining was evident in the necrotic lesions. In addition, extensive staining of neurons from dead fish was observed, but this occurred only occasionally in samples from live fish (Fig. 2).

\section{Virological examinations}

CPE was observed in cell cultures within 2 to $4 \mathrm{~d}$ of incubation after inoculation with tissue homogenates from 2 out of 7 rainbow trout from the first sampling and from all 10 fish from the second sampling of the primary outbreak. All samples with CPE tested positive for VHSV in IFT.

All fish that tested positive in cell cultures also tested positive for VHSV by RT-PCR. Furthermore, sequencing of a 286 bp PCR-product (Isolate NO/650/07, GenBank Accession number: AM920657) revealed a 98\% similarity with the glycoprotein (G) gene of VHSV from herring, isolate DK-4p168 (Einer-Jensen et al. 2005). The results of the virological examinations from the second sampling in November 2007 were confirmed by the CRL in Århus. The virus isolated at the CRL was designated NO-2007-50-385.

Similar results were obtained from samplings from the subsequent disease outbreaks at the 3 neighbouring farms, and the 286 bp sequence of the G-gene from these outbreaks was identical to that of the primary outbreak.

\section{Phylogenetic analysis}

To determine the phylogenetic relationship of the NO-2007-50-385 isolate to other VHSV isolates, the full length G-gene was sequenced (GenBank Accession number: EU547740). A phylogenetic analysis was performed using 34 reported full length G-gene sequences from isolates representing all known VHSV genotypes: Ia to Ie, II, III and IV (Fig. 3). The analysis

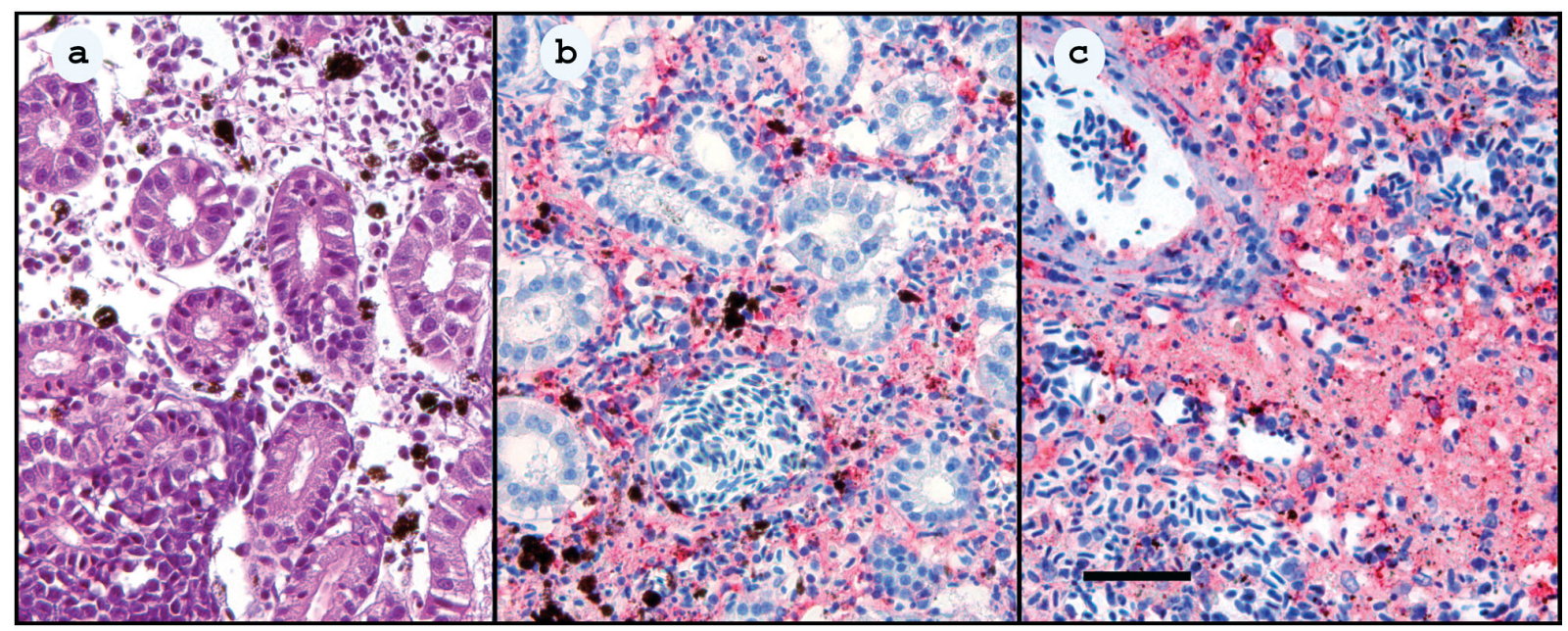

Fig. 1. Oncorhynchus mykiss. Pathology of haemorrhagic manifestation of VHS caused by VHSV Genotype III in rainbow trout. (a) Kidney, H\&E-stained section of necrotic haematopoietic tissue in between intact kidney tubules; some intact haematopoietic tissue is evident in lower left corner. (b) Kidney, immunohistochemistry (IHC) showing virus labelling (red colour) of necrotic haematopoietic tissue in between intact kidney tubules. (c) Spleen, immunohistochemistry showing virus labelling (red colour) of necrosis in spleen. Scale bar $=50 \mu \mathrm{m}$ (applies to $\mathrm{a}-\mathrm{c})$ 


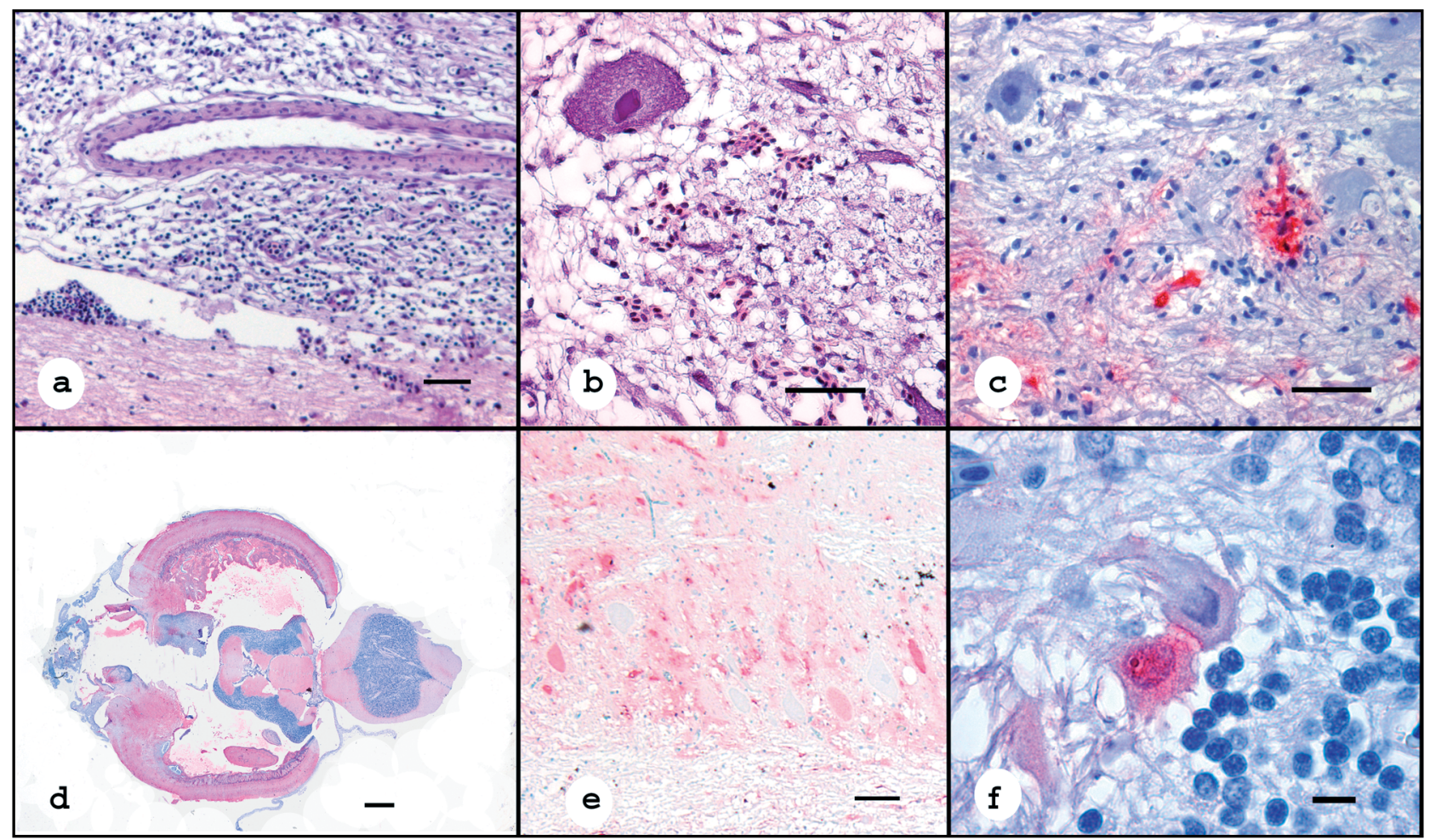

Fig. 2. Oncorhynchus mykiss. Pathology of nervous manifestation VHS caused by VHSV Genotype III in rainbow trout. (a) H\&Estained section showing extensive inflammation of meninges (scale bar $=50 \mu \mathrm{m}$ ). (b) H\&E-stained section showing focal haemorrhage and gliosis in the vicinity of a large neuron in the brain stem (scale bar $=50 \mu \mathrm{m}$ ). (c) Immunohistochemistry (IHC) of the same area as in (b) showing virus labelling (red colour) of a necrosis (scale bar $=50 \mu \mathrm{m}$ ). (d) IHC of transverse section showing extensive virus nucleoprotein labelling (red colour) (scale bar $=1 \mu \mathrm{m}$ ). (e) IHC of optic lobe showing extensive infection of neurons (red colour) (scale bar $=100 \mu \mathrm{m}$ ). (f) IHC of a section from the cerebellum showing virus labelling of a Purkinje cell (red colour) (scale bar $=10 \mu \mathrm{m})$

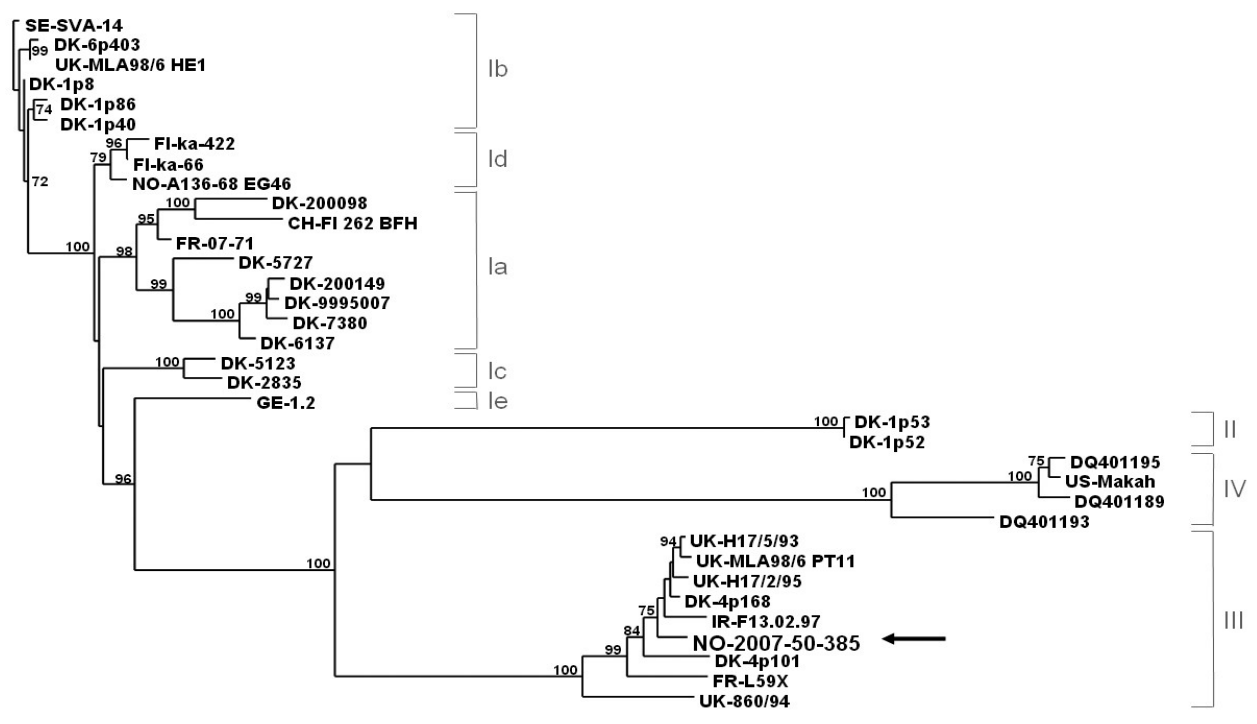

Fig. 3. Classification of the NO-2007-50-385 isolate as a Genotype III isolate. The phylogenetic tree was generated using 35 unique full length G-gene nucleotide sequences including the sequence of the NO-2007-50-385 isolate using the NeighborJoining distance algorithm. Bootstrap values have been obtained from 1000 reassembled data sets. Only bootstrap values above $70 \%$ were considered to be significant and are indicated at the nodes. Genotypes (Ia-e, II, III, IV) classified according to EinerJensen et al. (2004) are indicated with right square brackets. An arrow indicates the location of the unique Norwegian isolate NO-2007-50-385 with the Genotype III isolates 
identified the NO-2007-50-385 isolate as a Genotype III isolate. To determine which of the Genotype III isolates is most similar to the NO-2007-50-385 isolate, we compared all Genotype III full length G-gene sequences. The closest relationship was observed between NO-200750-385 and the DK-4p168 isolate (from herring, Skagerrak) with 10 nucleotide differences in the G-gene sequences. However, close relationships were also observed with the UK-H17/5/93 (from cod), UK-MLA98/6 PT11 (from Norway pout) and UK-H17/2/95 (from haddock), all from the North Sea (Table 1). The nucleotide sequence of the NO-2007-50385 isolate showed least similarity with UK-860/94 isolate (from turbot, western Scotland) and with isolates from fish caught relatively far away from the outbreak sites (Fig. 4).

\section{Infection trials}

Moribund infected fish showed clinical signs typical of VHS, e.g. exophthalmia, haemorrhages and ascites.

In the immersion trial of rainbow trout, the NO-2007-50-385 isolate produced cumulative mortalities of 62,71 and $77 \%$, with an average of $70 \%$ (Fig. 5). By i.p. injection in rainbow trout the cumulative mortality was 100, 97 and $100 \%$. In the immersion trial of Atlantic salmon the isolate produced no mortality. However, by i.p. injection in Atlantic salmon the cumulative mortality was $52 \%$ (Fig. 6).

The negative control rainbow trout had a cumulative mortality of $3 \%$ ( 1 dead fish at the end of the trial) and

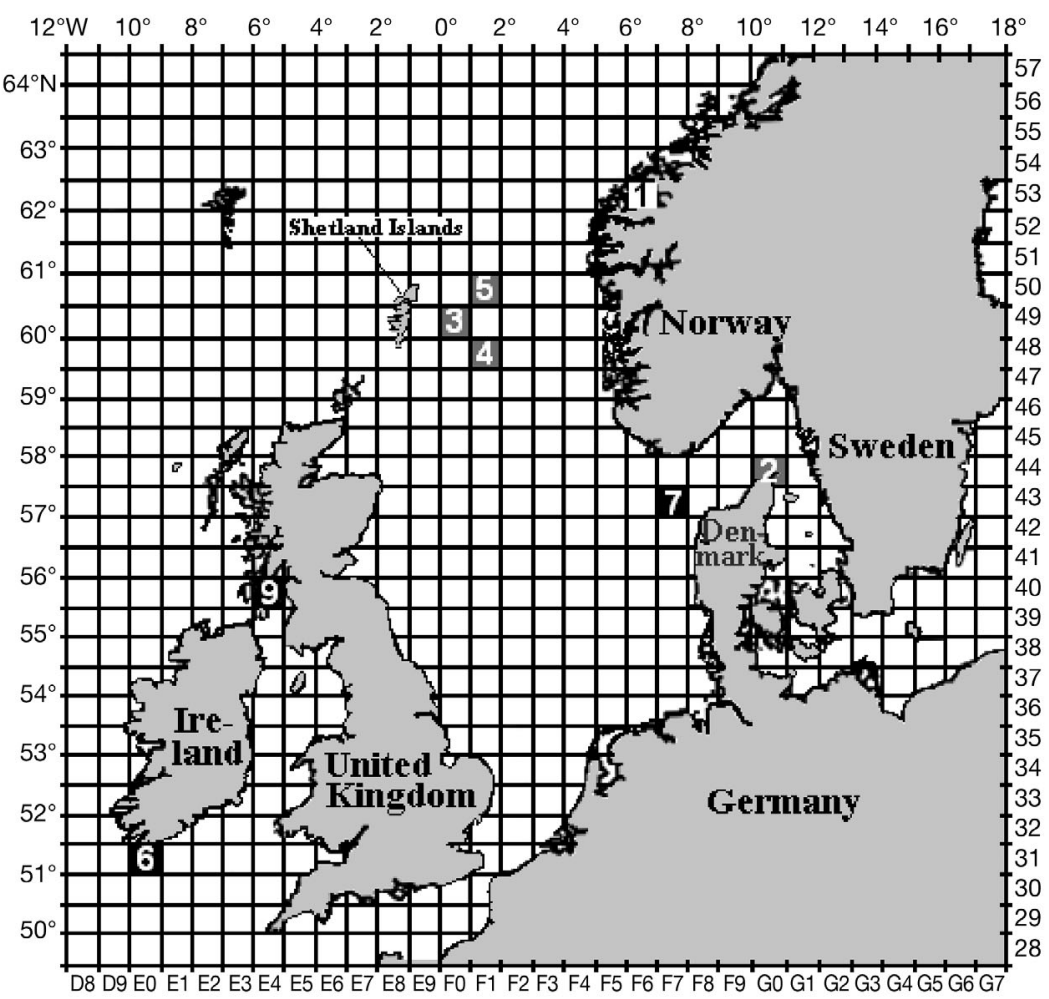

Fig. 4. Localisation of Genotype III isolates. Isolate 1 in white box is the Norwegian VHS outbreak isolate NO-2007-50-385. Isolates 2 to 5 in grey boxes are isolates with 10 to 13 nucleotide differences from NO-2007-50-385. Isolates 6,7 and 9 in black boxes are isolates with $\geq 18$ nucleotide differences

the positive control rainbow trout had a cumulative mortality of $100 \%$ (Fig. 5). No mortality was observed in the negative control group of Atlantic salmon. Since there are no known VHSV isolates highly pathogenic to Atlantic salmon, a positive control group for this species could not be included

Some of the infected fish that died during the test were examined virologically, and VHSV was isolated

Table 1. Differences between the NO-2007-50-385 isolate and other Genotype III VHSV isolates. Genotype III isolate names are according to Einer-Jensen et al. (2004). Numbers of nucleotide differences of full length G-gene sequences relative to NO-200750-385 are shown. Numbers 1 to 9 (left column) and the corresponding International Council for the Exploration of the Sea (ICES) numbers refer to the numbered squares in Fig. 4

\begin{tabular}{|lllcc|}
\hline & Isolate name & Place or origin & ICES number & $\begin{array}{c}\text { Nucleotide differences in full } \\
\text { length G-gene (1520 bp) }\end{array}$ \\
\hline 1 & NO-2008-50-385 & Norway & $53 F 6$ & - \\
2 & DK-4p168 & Skagerrak, Norway & 44 G0 & 10 \\
3 & UK-H17/5/93 & North Sea, E Shetland, UK & $49 F 0$ & 11 \\
4 & UK-MLA98/6PT11 & North Sea & $48 F 1$ & 12 \\
5 & UK-H17/2/95 & North Sea, E Shetland, UK & $50 \mathrm{~F} 1$ & 13 \\
6 & IR-F13.02.97 & Cape Clear, Ireland & $31 \mathrm{E} 0$ & 18 \\
7 & DK-4p101 & Skagerrak, Norway & $43 F 7$ & 26 \\
8 & FR-L59X & River Loire, France & - & 33 \\
9 & UK-860/94 & Gigha, W Scotland, UK & $40 \mathrm{E} 4$ & 47 \\
\hline
\end{tabular}




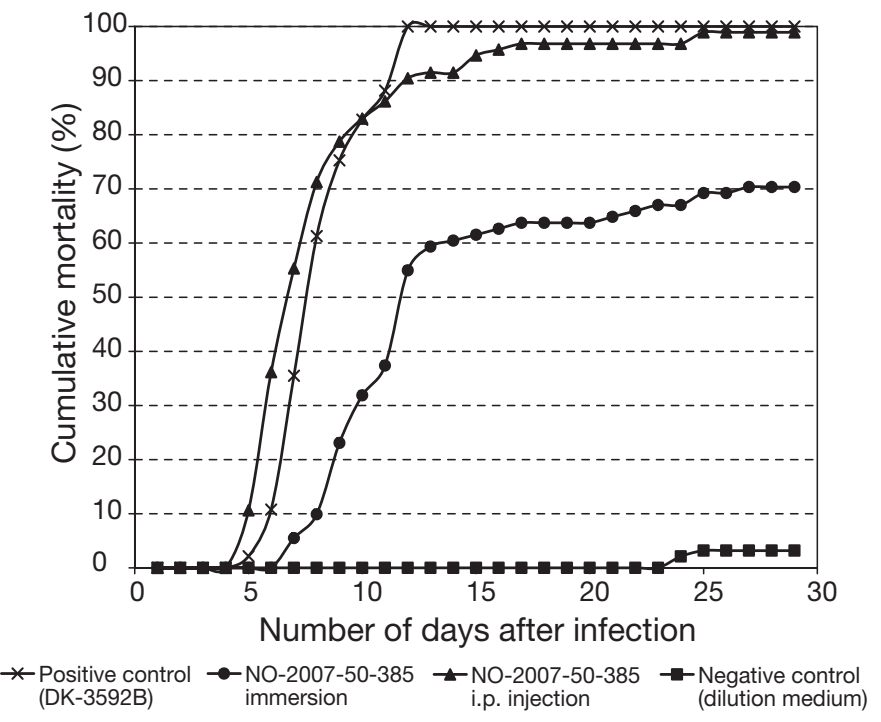

Fig. 5. Oncorhynchus mykiss. Mortality in rainbow trout after infection with VHSV NO-2007-50-385 by immersion and intraperitoneal (i.p.) injection. Negative and positive controls are by immersion only. Each group was kept in separate tanks during and after infection

from all these. VHSV was isolated from $36 \%$ of the surviving rainbow trout after infection by immersion, whereas no VHSV was isolated from the surviving Atlantic salmon after immersion. Of 12 surviving Atlantic salmon tested, 3 (25\%) carried the virus after i.p. injection (Table 2).

The full length G-gene of VHSV from a single rainbow trout and single Atlantic salmon that died during the in-

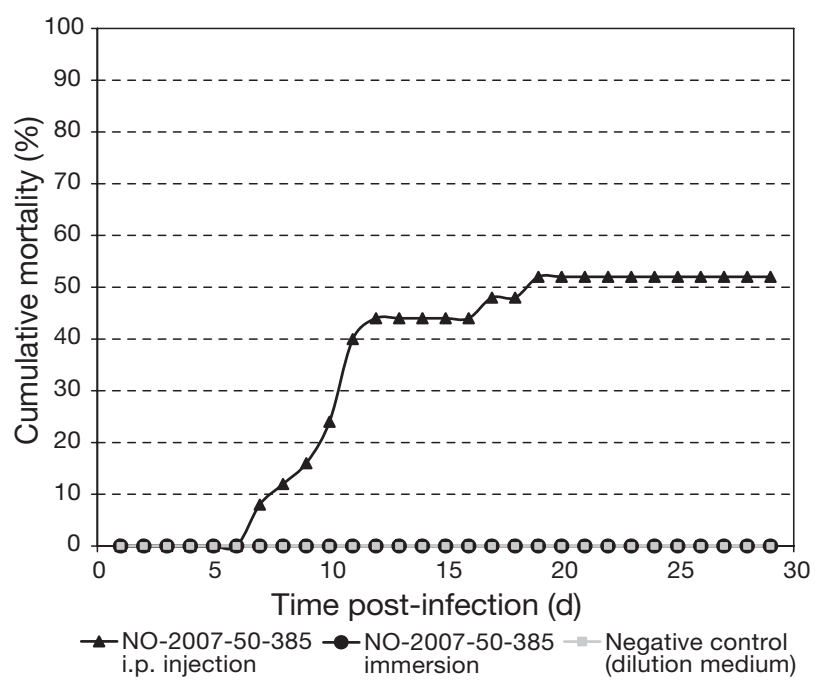

Fig. 6. Salmo salar. Mortality in Atlantic salmon after infection with VHSV NO-2007-50-385 by immersion and intraperitoneal (i.p.) injection. Positive control is not included as no highly pathogenic VHSV isolate is available. Negative control is by immersion only. Each group was kept in separate tanks during and after infection fection trial was sequenced and there was $100 \%$ identity with the NO-2007-50-385 strain used in the trials.

\section{DISCUSSION}

In this paper we describe an outbreak of VHS in seafarmed rainbow trout caused by VSHV belonging to Genotype III. The outbreak occurred on the west coast of Norway in 2007 (Fig. 4) and is the first record of VHS in a salmonid species caused by this genotype. The VHSV Genotype III has hitherto only caused outbreaks of VHS in marine species, i.e. farmed turbot (Ross et al. 1995), although it has been isolated from a variety of wild marine, non-salmonid, fish species (Einer-Jensen et al. 2004, Snow et al. 2004, Skall et al. 2005). Norway has not experienced outbreaks of VHS in rainbow trout since 1974, which at that time were caused by VHSV of Genotype Id (isolate NO-A163-68 EG46 in Fig. 3).

The present disease outbreak in Storfjorden, Norway, started with a slightly elevated mortality and a widespread ataxia shifting rapidly in extent. This pattern had a striking resemblance to the descriptions of outbreaks in the early history of VHS. The mortality in VHS outbreaks can be very variable, and a wide range of disease signs have been attributed to several forms of the disease (Schäperclaus 1979). Affected fish corresponding to both the acute haemorrhagic form and the chronic nervous and anaemic form were observed. Pathological findings including internal haemorrhages and necrosis of haematopoietic, but not of excretory kidney tissue, were consistent with the haemorrhagic form of VHS. In ataxic fish without haemorrhagic lesions we found mononuclear meningoencephalitis typical for viral infection. The immunohistochemistry examinations demonstrated the presence of VHSV directly in the lesions, thus providing evidence for an etiological role of the isolated virus.

In a population of several million fish, as in this farm system, the occurrence of several infections and diseases must be expected. Low levels of IPNV were detected in 4 fish, but no other infections were recognised (results not shown). As no pathological lesions corresponding to IPN were found, this finding probably reflects the high prevalence of fish in salmonid aquaculture in Norway covertly infected with IPNV. During the winter, skin ulcers especially due to Moritella viscosa developed in fish at the on-growing farms (results not shown). As VHS causes anaemia and leukopenia (Wolf 1988), immunodeficiency causing increased problems with other diseases can also be an effect of VHS. In the recent VHS outbreaks at Åland, Finland, flexibacterial problems appear to have increased in the presence of VHS (P. Vennerström, EVIRA, pers. comm.). 
Table 2. Virological examination by cell cultivation followed by identification of virus by ELISA of rainbow trout and Atlantic salmon included in infection trials with VHSV isolate NO-2007-50-385. i.p. = intraperitoneal

\begin{tabular}{|llc|}
\hline Group & Comments/Observations & VHSV positive fish/no. of fish tested \\
\hline Rainbow trout, immersion & Fish dying early in infection trial & $8 / 8$ \\
Rainbow trout, immersion & Surviving trout 29 d after infection & $10 / 28$ \\
Atlantic salmon, immersion & Surviving salmon 29 d after immersion & $0 / 20$ \\
Atlantic salmon, i.p. injection & Fish dying early in infection trial & $3 / 3$ \\
Atlantic salmon, i.p. injection & Surviving salmon 29 d after injection & $3 / 12$ \\
\hline
\end{tabular}

VHSV from all the 4 sites described in this report were identical in the 286 nucleotides (nt) part of the Ggene, indicating that the VHSV from all these sites originated from a common source. Furthermore, the phylogenetic analysis of the full-length G-gene sequence of isolate NO-2007-50-385 verified that the Norwegian VHSV isolate clustered with Genotype III, and that the isolate represents a unique isolate not previously described.

In experimental infection trials, the Norwegian VHSV Genotype III isolate induced a mortality in rainbow trout of approximately $70 \%$ when infected by immersion, which is at the same level as the mortality in similar infection trials (range, 46 to $89 \%$ ) using Genotype Ia VHSV isolates from outbreaks in freshwater rainbow trout farms (Skall et al. 2004). When infected by i.p. injection, the Norwegian isolate produced nearly $100 \%$ mortality. In comparison, VHSV Genotype III isolates from farmed turbot and wild marine fish resulted in maximum $3 \%$ mortality in rainbow trout when infected by immersion, and maximum $20 \%$ when i.p. infected (Skall et al. 2004). Thus, the Norwegian isolate represents a rainbow trout pathogenic strain of VHSV Genotype III not previously reported. Sequencing of the full length G-gene of the re-isolated virus from the experimentally infected rainbow trout and Atlantic salmon revealed $100 \%$ identity with the G-gene sequence of the virus isolate NO2007-50-385 used for infection. Since VHSV was not detected in the test fish before the infection trials, this confirms that the high mortality in the rainbow trout was caused by the new Norwegian VHSV isolate. A recent in vitro study shows that a VHSV strain highly pathogenic to rainbow trout translocated rapidly through polarized gill epithelial cell cultures compared with a low pathogenic strain (Brudeseth et al. 2008). This may explain the differences in mortality between infection by i.p. injection and immersion, and indicates that translocation through the gills may be the step that limits pathogenicity for successful infection in various salmonid species.

Standardized infection trials are important for evaluation of the pathogenicity of VHSV. The reported monthly mortality at site level at the time of the primary outbreak may be regarded as moderate (approximately 1.7 to $1.8 \%$ ), whereas the observed mortality in rainbow trout bath-infected with the causative virus was approximately $70 \%$ (Fig. 5) However, due to the uncertainty about the reported mortality during the outbreak, it was difficult to compare the mortality observed in the field with the infection trial.

The source of VHS infection in the Norwegian rainbow trout farms is not known, but due to the genotype of the causative virus, together with the fact that the highest sequence similarity is observed towards VHSV isolates from northern European waters, a marine source is most likely. For the outbreaks of VHS in sea-farmed rainbow trout in Sweden (Nordblom \& Novell 2000), the isolated virus (Genotype Ib) was almost identical to isolates found in the adjacent marine environment (EinerJensen et al. 2004), indicating a direct transmission of virus from species in the surrounding waters. The outbreaks of VHS in Finnish rainbow trout farms in the Baltic Sea occurred in brackish water. Although a definite origin of the outbreaks was not identified, because the causative virus was not genetically related to those detected in marine species from this area, it was still suggested that wild fish were the source of the primary infection (Raja-Halli et al. 2006).

Screening of herring and sprat caught at the outlet of Storfjorden resulted in detection of VHSV in 2 out of 120 herrings examined. However, these VHSV isolates were reported to cluster with VHSV Genotype Ib (A. Nylund pers. comm.). Farms raising cod and saithe are located in the same fjord system as the rainbow trout farms with VHS. In the case of saithe, wild fish are caught and kept in net pens for further growing. Farmed cod and saithe are both fed raw processed fish of marine origin. All non-affected fish farms in the fjord (Storfjorden), including both marine and salmonid species, were examined for the presence of VHSV by RT-PCR and cell culture with negative results (results not shown). The latest sampling for the Norwegian VHS/IHN surveillance program from the outbreak 
sites was in April 2006 with negative results. Even though VHSV was not detected in the marine farms, the prevalence could be lower than that needed for virus detection by examination of 30 fish from each site. According to information from NFSA, the rainbow trout were fed commercial dried pelleted feed that had been processed in high temperatures and under conditions that would kill microorganisms.

The fish on the primary outbreak site were not removed and disposed of before 5 mo after the VHS diagnosis was confirmed. Within this time, the disease was detected on 3 neighbouring rainbow troutfarming sites operated by the same owner. The outbreaks of VHS in Storfjorden occurred within a limited time period. It is therefore difficult to determine whether the virus was introduced by a single incidence into the primary outbreak site and thereafter spread to the other farms, or whether a parallel introduction to the other rainbow trout farms in question had occurred.

Whether the virus causing the present outbreak of VHS was transmitted directly from a possible marine source or whether an adaptation to rainbow trout had occurred before disease outbreak is not known. Although marine VHSV isolates are not, in general, associated with disease in rainbow trout (Skall et al. 2004), the present study has demonstrated that VHSV of Genotype III can be harmful to farmed rainbow trout. In continental European aquaculture, VHS is still the most serious fish disease. Mounting evidence suggests that all VHS viruses can develop high pathogenicity in many different fish species given time and opportunity. The introduction of VHSV Genotype IV to the Great Lakes appears to be a worst case scenario in this respect. Since VHSV belongs to a group of RNA viruses showing high adaptability to diverse fish species, the presence of VHSV in Norwegian rainbow trout aquaculture may represent a threat to the Atlantic salmon farming industry.

In conclusion, the Norwegian VHSV Genotype III, NO-2007-50-385, is a new contagious strain that caused outbreak of VHS in both sea-farmed rainbow trout and in experimentally infected rainbow trout and Atlantic salmon fingerlings. The source of infection has not been identified, but virus originating from wild or farmed marine species is most likely.

Acknowledgements. L. B. Rønneberg at the fish health service Fiske-Liv AS, Ålesund, Norway, is greatly acknowledged for providing information of clinical signs and gross pathology of the affected fish. The author thanks M. J. Hjortaas for her contribution to the design of primers. The skilled technical assistance of the staff at the Section of Virology and Serology and the Section of Fish Health, NVI, Norway, and at CRL Århus, is greatly appreciated. We also thank Dr. H. Sindre for critically reading of the manuscript.

\section{LITERATURE CITED}

Anonymous (2001) 2001/183/EC: commission decision of 22 February 2001 laying down the sampling plans and diagnostic methods for the detection and confirmation of certain fish diseases and repealing Decision 92/532/EEC. Off J Eur Communities L 67:65-76

Betts AM, Stone DM (2000) Nucleotide sequence analysis of the entire coding regions of virulent and avirulent strains of viral haemorrhagic septicaemia virus. Virus Genes 20: 259-262

- Brudeseth BE, Castric J, Evensen O (2002) Studies on pathogenesis following single and double infection with viral hemorrhagic septicemia virus and infectious hematopoietic necrosis virus in rainbow trout (Oncorhynchus mykiss). Vet Pathol 39:180-189

Brudeseth BE, Skall HF, Evensen O (2008) Differences in virulence of marine and freshwater isolates of viral hemorrhagic septicemia virus in vivo correlate with in vitro ability to infect gill epithelial cells and macrophages of rainbow trout (Oncorhynchus mykiss). J Virol 82: 10359-10365

> Einer-Jensen K, Ahrens P, Forsberg R, Lorenzen N (2004) Evolution of the fish rhabdovirus viral haemorrhagic septicaemia virus. J Gen Virol 85:1167-1179

Einer-Jensen K, Ahrens P, Lorenzen N (2005) Parallel phylogenetic analyses using the N, G or Nv gene from a fixed group of VHSV isolates reveal the same overall genetic typing. Dis Aquat Org 67:39-45

> Elsayed E, Faisal M, Thomas M, Whelan G, Batts W, Winton J (2006) Isolation of viral haemorrhagic septicaemia virus from muskellunge, Esox masquinongy (Mitchill), in Lake St Clair, Michigan, USA reveals a new sublineage of the North American genotype. J Fish Dis 29:611-619

Enzmann PJ, Konrad M (1985) Inapparent infections of brown trout with VHS-virus. Bull Eur Assoc Fish Pathol 5:81-83

Fijan N, Sulimanovic D, Bearzotti M, Muzinic D and others (1983) Some properties of the Epithelioma papulosum cyprini (EPC) cell line from carp (Cyprinus carpio). Ann Virol Inst Pasteur 134:207-220

Groocock GH, Getchell RG, Wooster GA, Britt KL and others (2007) Detection of viral hemorrhagic septicemia in round gobies in New York State (USA) waters of Lake Ontario and the St. Lawrence River. Dis Aquat Org 76:187-192

Isshiki T, Nishizawa T, Kobayashi T, Nagano T, Miyazaki T (2001) An outbreak of VHSV (viral hemorrhagic septicemia virus) infection in farmed Japanese flounder Paralichthys olivaceus in Japan. Dis Aquat Org 47:87-99

Jørgensen PEV (1982) Egtved virus: occurrence of inapparent infections with virulent virus in free-living rainbow trout, Salmo gairdneri Richardson, at low temperatures. J Fish Dis 5:251-255

Jukes T, Cantor C (1969) Evolution of protein molecules. In: Munro HN (ed) Mammalian protein metabolism, Vol III. Academic Press, New York, p 21-32

> Lorenzen N, Olesen NJ, Jørgensen PEV (1988) Production and characterization of monoclonal antibodies to four Egtved virus structural proteins. Dis Aquat Org 4:35-42

> Lorenzen N, Olesen NJ, Jørgensen PEV (1993) Antibody response to VHS virus proteins in rainbow trout. Fish Shellfish Immunol 3:461-473

Lorenzen E, Carstensen B, Olesen NJ (1999) Inter-laboratory comparison of cell lines for susceptibility to three 3 viruses: VHSV, IHNV and IPNV. Dis Aquat Org 37:81-88

Lumsden JS, Morrison B, Yason C, Russell S and others (2007) Mortality event in freshwater drum Aplodinotus grunniens from Lake Ontario, Canada, associated with viral 
haemorrhagic septicemia virus, type IV. Dis Aquat Org 76:99-111

Meyers TR, Short S, Lipson K (1999) Isolation of the North American strain of viral hemorrhagic septicemia virus (VHSV) associated with epizootic mortality in two new host species of Alaskan marine fish. Dis Aquat Org 38:81-86

Nishizawa $T$, Iida $H$, Takano $R$, Isshiki $T$, Nakajima $K$, Muroga K (2002) Genetic relatedness among Japanese, American and European isolates of viral hemorrhagic septicemia virus (VHSV) based on partial G and P genes. Dis Aquat Org 48:143-148

Nordblom B, Norell AW (2000) Report on an outbreak of VHS (viral hemorrhagic septicaemia) in farmed fish in Sweden. Report for the Standing Veterinary Committee. Swedish Board of Agriculture, Department for Animal Production and Health, Jönköping

Raja-Halli M, Vehmas TK, Rimaila-Parnanen E, Sainmaa S, Skall HF, Olesen NJ, Tapiovaara H (2006) Viral haemorrhagic septicaemia (VHS) outbreaks in Finnish rainbow trout farms. Dis Aquat Org 72:201-211

Ross K, McCarthy U, Huntly PJ, Wood BP and others (1995) A outbreak of viral haemorragic septicaemia (VHS) in turbot (Scophthalmus maximus) in Scotland. Bull Eur Assoc Fish Pathol 14:213-214

Schäperclaus W (1979) Fischkrankheiten 4. Auflage. Akademie-Verlag, Berlin

Schlotfeldt HJ, Ahne W, Jørgensen PEV, Glende W (1991) Occurrence of viral haemorrhagic septicaemia in turbot (Scophthalmus maximus) - a natural outbreak. Bull Eur Assoc Fish Pathol 11:105-107

Skall HF, Slierendrecht WJ, King JA, Olesen NJ (2004) Experimental infection of rainbow trout Oncorhynchus mykiss with viral haemorrhagic septicaemia virus isolates from

Editorial responsibility: Mark Crane,

Geelong, Victoria, Australia
European marine and farmed fishes. Dis Aquat Org 58: 99-110

Skall HF, Olesen NJ, Mellergaard S (2005) Viral haemorrhagic septicaemia virus in marine fish and its implications for fish farming: a review. J Fish Dis 28:509-529

Snow M, Cunningham CO, Melvin WT, Kurath G (1999) Analysis of the nucleoprotein gene identifies distinct lineages of viral haemorrhagic septicaemia virus within the European marine environment. Virus Res 63:35-44

Snow M, Bain N, Black J, Taupin V and others (2004) Genetic population structure of marine viral haemorrhagic septicaemia virus (VHSV). Dis Aquat Org 61:11-21

- Taksdal T, Olsen AB, Bjerkas I, Hjortaas MJ, Dannevig BH, Graham DA, McLoughlin MF (2007) Pancreas disease in farmed Atlantic salmon, Salmo salar L., and rainbow trout, Oncorhynchus mykiss (Walbaum), in Norway. J Fish Dis 30:545-558

Traxler G, Kieser D, Evelyn TPT (1995) Isolation of North American strain of VHS virus from farmed Atlantic salmon. In: Margolis L (ed) Aquaculture update no. 72. Fisheries and Oceans Canada, Aquaculture Division, Pacific Biological Station, Nanaimo

Walker PJ, Benmansour A, Dietzgen R, Fang RX and others (2000) Family Rhabdoviridae. In: Van Regenmortel MHV, Fauquet CM, Bishop DHL, Carstens EB and others (eds) Virus taxonomy. Classification and nomenclature of viruses. Academic Press, San Diego, CA, p 563-583

Wolf K (1988) Viral hemorrhagic septicemia. In: Wolf K (ed) Fish viruses and fish viral diseases. Cornell University Press, Ithaca, NY, p 217-249

Wolf K, Gravell M, Malsberger RG (1966) Lymphocystis virus: isolation and propagation in centrarchid fish cell lines. Science 151:1004-1005

Submitted: December 17, 2008; Accepted: April 7, 2009

Proofs received from author(s): May 29, 2009 